\title{
OBSESSIVE-COMPULSIVE DISORDER: RETROSPECTIVE STUDY ON CLINICAL CHARACTERISTICS AND FAMILY HISTORY IN OUTPATIENTS CARE
}

\author{
FLAVIO SOARES ARAUJO ${ }^{1}$, RODRIGO REBOUCAS DE CASTRO ${ }^{2}$ \\ \& HAMMEL PHILLIPE DOS SANTOS AMORIM ${ }^{3}$ \\ ${ }^{1}$ Professor ofPsychiatryat Universidade Federal de Alagoas, Brazil \\ ${ }^{2}$ Medical Student at Universidade Federal de Alagoas, Brazil
}

${ }^{3}$ Medical Studentat Universidade Estadual de Ciências da Saúde de Alagoas, Brazil

\begin{abstract}
One of the main factors associated with Obsessive-Compulsive Disorder (OCD) etiology, is heredity. There are evidences showing that, the mean age at onset of symptoms is lower among relatives and are associated with a higher morbidity risk, for OCD. Objectives: investigate the clinical characteristics of the disorder among patients with family history and those without a family history. Methods: Retrospective analysis of 114 medical records of patients diagnosed with OCD and followed-up due to this disorder. Results: $22 \%$ had a family history of OCD (group A) and $78 \%$ had no family history (group B). The mean age at onset of symptoms in group A was lower and means age at onset of treatment in this group, was also lower. Doubt (obsession) and hoarding (compulsion) were more frequent in group A. The symptoms for the group, with positive family history (group A) had higher mean scores in Yale-Brown ObsessiveCompulsive Scale (Y-BOCS). Conclusion: OCD family history can be a risk factor, to an increased severity of symptoms. KEYWORDS: Obsessive-Compulsive Disorder, Family History \& Hoarding
\end{abstract}

Received: Sep 16, 2017; Accepted: Oct 06, 2017; Published: Oct 24, 2017; Paper Id.: IJESROCT201719

\section{INTRODUCTION}

Obsessive Compulsive Disorder (OCD), is characterized primarily by obsessive ideas or recurrent compulsive behaviors. It is a common psychiatric disorder, with an estimated lifetime prevalence ranging between $0.3 \%$ and $2.2 \%$ in adults and approximately $0.7 \%$ in children and adolescents, according to data based on the Composite International Diagnostic Interview (Fontenelle, Mendlowicz \& Versjani, 2006). A remarkable impairment in social interaction and academic development, are signs of distress caused by recurrent obsessions and compulsions in children, with this psychiatric disorder (Johnson, 2017). It also affects equally men and women, with symptoms beginning early and gradually in infancy (Sasson, Zohar, Chopra, Lustig, Iancu \& Hendler, 1997). A large proportion of OCD patients are single, especially males, however, 35\% of males were married, when compared to $60 \%$ to $75 \%$ of females. This difference can be partly explained by the fact that, the onset of OCD is earlier in men (Del-Porto, 2001). It is usually a chronic condition with a fluctuation in intensity of symptoms, over time (Torres \&Smaira, 2001).

One of the main factors associated with the etiology of OCD is heredity, since it has been perceived that, OCD would have a family component. There is enough evidence from genetic epidemiological studies, particularly family studies with twins, that OCD not only aggregates in families, but also that it would be, at least partially, 
genetically determined (Nestadt, Samuels, Bienvenu, Liang, LaBuda, Grados \& Hoehn-Saric, 2000; Pauls \& Alsobrook, 1999; Sasson et al, 1997; Van Grootheest, Cath, Beekman \& Boomsma, 2005).

In relation to the familial etiology of the disorder, there are studies with controversial results, being difficult to make comparisons due to the different diagnostic criteria and methodologies applied. The most recent studies have used standardized diagnostic criteria and more appropriate methodologies. Data from these studies suggest that, there is a higher prevalence of OCD, obsessive-compulsive symptoms, Tourette's Disorder, and motor tic disorder or chronic vocal disorder among relatives of OCD patients (Gonzalez, 1999). There is also evidence of an earlier onset of obsessive-compulsive symptoms, with a higher risk of morbidity among family members (Brakoulias, Starcevic, Sammut, Berle, Milicevic, Moses \& Hannan, 2011; Pauls, Raymond, Robertson, 1991). An Iranian group investigated the association of the serotonin transporter gene (SLC6A4) in OCD patients, and they found a strong correlation with OCD in man, additionally, it was stronger in those with a family history of psychiatric disorders (Rashidi et al., 2017). In several studies with twins, the concordance rates of OCD among monozygotic twins range from $53 \%$ to $87 \%$, while for dizygotic twins, they range from $22 \%$ to $47 \%$ (Carey \& Gottesman, 1981; Rasmussen \& Tsuang, 1986). In children, the symptoms were seen to be transmitted by genes inherited, with an influence varying from $45 \%$ to $65 \%$, when using a dimensional technique no analyze the data obtained (Van Grootheest, 2005). These studies corroborate the hypothesis that, genetic factors contribute in the etiology of OCD.

Segregation analysis studies, such as those of Cavalini, Pasquale, Bellodi \& Smeraldi (1999), performed with 107 families of OCD patients concluded that, the most compatible transmission model would be the autosomal, dominant with greater gene penetrance in women. Nevertheless, the studies by Nicoline, Hanna, Baxter, Schwartz, Weissbacker\& Spence (1991), carried out with 24 families of patients with OCD, concluded that, it is not possible to exclude the autosomal recessive transmission model. A study by Alsobrook, Leckman, Goodman, Rasmussen \&Pauls (1999) has concluded that, in families of patients with the highest score for symmetry and ordering symptoms, there is a probable implication of a major effect gene. In association studies, serotonergic and dopaminergic receptor genes have been investigated, since these neurotransmitters are likely play a role in the pathophysiology of OCD (Gonzalez, 2001).

The uniformity of symptoms independently of geographical, historical, ethnical, cultural or economic differences suggests a common biological factor (Del-Porto, 2001). The evidence of OCD with a positive family history, despite the lack of definition of the genetic aspects of the disease, allows us to investigate the clinical characteristics between patients with family history disorder and those with no family disorder background. This is the aim of the current work, performed through medical records review of patients, diagnosed with OCD and ambulatory follow-up due to the disorder.

\section{METHODS}

It has been retrospectively studied 114 subjects from a private clinic in the city of Maceió, capital of the state of Alagoas, Brazil, between February of 2005 and February of 2014. The inclusion criteria for the study were the diagnosis of OCD according to the tenth edition of the International Classification of Diseases (ICD-10). The instrument used to collect information addressed the issue of the data, investigated by the main examiner, the mentor of this study. The data collected was: date of birth, sex, schooling, color, religion, marital status, profession, current patient age, age of onset of symptoms, age of treatment for OCD, family history of the patient, list of symptoms of the Yale-Brown Obsessive-Compulsive Scale (Y-BOCS) and Y-BOCS scores. The family history was obtained through a semi-structured interview with patients and 
their relatives. The project of this study was approved by the Research Ethics Committee of the Federal University of Alagoas.

\section{RESULTS}

Twenty-five patients (22\%) had a family history of OCD (Group A) and 89 (78\%) had no family history of OCD (Group B). Demographic data regarding the age of onset of symptoms and treatment, are presented in Table 1. The mean age of onset of symptoms was 18.6 years for the sample, with a family history and 22.1 years for the group with no family history. The mean age for beginning treatment was earlier for group A and later for B, being 25.2 years for group A and 27.4 years for group B.

Table 1: Comparison of Age of Onset of Symptoms and Age of Initiation of

Treatment between Groups A and B

\begin{tabular}{|l|l|l|c|}
\hline \multicolumn{1}{|c|}{ Variables } & \multicolumn{1}{|c|}{$\begin{array}{c}\text { Group A (n= 25) } \\
\text { Mean (SD) }\end{array}$} & $\begin{array}{c}\text { Group B }(\mathbf{n}=\mathbf{8 9}) \\
\text { Mean (SD) }\end{array}$ & \multicolumn{1}{c|}{ p } \\
\hline $\begin{array}{l}\text { Onset of symptoms } \\
\text { (age in years) }\end{array}$ & $18,6(7,53)$ & $22,1(8,13)$ & $<0.001$ \\
\hline $\begin{array}{l}\text { Initiation of treatment } \\
\text { (age in years) }\end{array}$ & $25,2(11,3)$ & $27,4(13,4)$ & 0,048 \\
\hline
\end{tabular}

$\mathrm{SD}=$ standard deviation and $\mathrm{n}=$ sample size; Source: created by the author.

Concerning to the frequency of the most common types of symptoms, it was observed that, group A had a higher rate of the obsessions of doubt (28\%) and compulsions of collecting (36\%), when comparing to group B, which presented $7 \%$ and $10 \%$, respectively. This finding is reported in Table 2. Moreover, in regards to Yale-Brown's ObsessiveCompulsive Scale (Y-BOCS), group A had the highest obsessive subscale score (11.68) and compulsory (12, 57), compared to the group with no family history 9.58 and 10.34 , respectively. The total mean point was 24.30 for group A and 19.98 for group B.

Table 2: Comparison between the Most Frequent Types of Obsessions and Compulsions between Groups $\mathrm{A}$ and $\mathrm{B}$

\begin{tabular}{|c|c|c|c|}
\hline Variables & $\begin{array}{c}\text { Group A }\left(n^{1}=25\right) \\
n^{0} \text { Patients }(\%)\end{array}$ & $\begin{array}{c}\text { Group B }\left(n^{1}=89\right) \\
n^{0} \text { Patients }(\%)\end{array}$ & $\mathbf{p}$ \\
\hline $\begin{array}{l}\text { Obsessions } \\
\text { (Doubts) }\end{array}$ & $7(28)$ & $6(7)$ & 0,025 \\
\hline $\begin{array}{l}\text { Compulsions } \\
\text { (Hoarding) }\end{array}$ & $9(36)$ & $9(10)$ & 0,028 \\
\hline
\end{tabular}

$\mathrm{n}=$ sample size; Source: created by the author.

Table 3: Comparison of the Intensity of Obsessive-Compulsive Symptoms between Groups A and B

\begin{tabular}{|l|c|c|c|}
\hline \multicolumn{1}{|c|}{ YBOCS } & $\begin{array}{c}\text { Group A (n= 25) } \\
\text { Mean (SD) }\end{array}$ & $\begin{array}{c}\text { Group B (n= 89) } \\
\text { Mean (SD) }\end{array}$ & p \\
\hline Obsessionssubscale & $11,68(4,87)$ & $9,58(5,78)$ & 0,021 \\
\hline Compulsionssubscale & $12,57(3,43)$ & $10,34(6,12)$ & $\leq 0,001$ \\
\hline Total score & $24,30(8,15)$ & $19,98(11,8)$ & $\leq 0,001$ \\
\hline
\end{tabular}

$\mathrm{SD}=$ standard deviation; $\mathrm{n}=$ sample size; YBOCS = Yale-Brown Obsessive-Compulsive Scale.

Source: created by the author.

\section{DISCUSSIONS}

The study showed that, $22 \%$ of patients with OCD analyzed, had a family history of the disorder, a statistic 
consistent with many similar studies. In are searching with families of patients with OCD, performed by Nicolini, Weissbecker, Mejia \& Sanchez (1993) in Latin America, 268 first degree relatives and 187 2nd degree relatives of 27 probands, with OCD were investigated, and it was seen family history in $30 \%$ of the patients. Gonzalez (2011) observed, in Brazil, a prevalence of $6.9 \%$ of OCD among 173 first-degree relatives of 30 OCD probands and $1.4 \%$ of OCD, among controls $(\mathrm{n}=348)$, also detected a prevalence of $19.1 \%$ of obsessive and compulsive symptoms, among relatives of OCD patients and $3.2 \%$ of these symptoms among the controls.

In an investigation carried out in the Obsessive-Compulsive Spectrum Disorder outpatient care at the President Vargas Maternal and Child Hospital, analyzing information from 84 patients with OCD, found a positive family history in $17.8 \%$ of the patients (Ferrão, Aguiar, Minuzzi, Grillo, Lopes \& Rosa, 2004). Paul et al (2005), conducted a survey through structured psychiatric interviews with first degree relatives of 100 probands with OCD $(n=466)$ and 133 first degree relatives of 33 healthy subjects. They noted $10.9 \%$ of OCD and $7.9 \%$ of subclinical OCD in the first degree relatives of the probands, however, for controls; the rates were $1.9 \%$ of OCD and $2.0 \%$ of subclinical OCD. Black, Stumpf, McCormick, Allen \& Blum (2013), in a review study of Iowa families with OCD, which had previously concluded that the disorder was not familial, found a prevalence of $10.7 \%$ of OCD, among 168 first degree relatives of OCD probands and $3.8 \%$ of OCD among controls $(\mathrm{n}=184)$.

Epidemiological reviews confirmed observations from clinical studies that OCD install predominantly in childhood, adolescence and early adulthood (Nelson \& Rice, 2007; Karno\& Golding, 1991). The mean age of onset of symptoms for the group with family history was lower (18.6 years), in comparison to the group with no family history (22.1 years). Likewise the study by Ferrão et al (2004), the onset of symptoms in the family history group, was earlier (17.8 years) compared to the group with no family history (20.8 years). Furthermore, in a research by Nicolini et al (1993), they noticed the age of onset of symptoms lower for the family history group than for the probands, without a family history of OCD. In a study by Nestadt et al (2000), any case of late-onset OCD, after 18 years was found, what supports early-onset OCD to be more "familial" and the greater the number of OCD cases in the same family, the earlier the outset in the index case. In an investigation by campus (1998), patients who had early onset of obsessive-compulsive symptoms presented greater tic-like and hoarding compulsions (such as inability to discard and excessive acquisition), as well as a greater severity in Y-BOCS compulsions subscale and more comorbid disorders. Additionally, Arumughama et al. (2014), in a retrospective study that reviewed 802 patient records, noticed that within this sample, about 152 patients presented a family history of OCD and $44 \%$ of them developed symptoms, under the age of 18 years. In this same study, mean age of patients with family history was 19.9 years and those without family history were 22.1 years, corroborating our findings.

The mean age for beginning treatment in the group with a family history (25.2 years) was lower than in the group with no family history (27.4 years). This fact was also evidenced in a study by Ferrão et al. (2004), in which the mean age of onset of treatment was lower in the group, with a family history (28.6 years) than in the group with no family history (30.6 years). They also noticed that, although patients with a family history of OCD had onset of symptoms at an earlier age, they took an average of 2 years longer than patients without a family history to seek medical help, evidencing the environmental influence on maintaining symptoms.

In this research, a higher frequency of hoarding was observed in the group with a positive family history, $36 \%$ versus $10 \%$. Same pattern was found by Ferrão et al., 26.6\% versus $4.3 \%$. Hoarding is one of the main compulsions and according to Moreno et al. (1995), it is a risk factor for a darker prognosis, in OCD. Patients with hoarding have lower 
levels of insight and adherence to treatment (Greenberg, 1987; Mataix-Cols, 2002). A survey with 578 undergraduate students found that, hoarding symptoms were more likely to happen in individuals with a family history of hoarding, along with a greater symptomatology (Woerner, Selles, De Nadai, Salloum \& Storch, 2017). On a relatively smaller proportion, this fact was also demonstrated in the study by Arumugham et al. (2014), in which frequency was $11 \%$ of hoarding among the group, with a positive family history versus $10 \%$.

The symptoms in the group with a positive family history, presents higher scores in the Y-BOCS scale, as shown in Table 3, thus suggesting a greater intensity for disorder manifestation, associated with genetic heritage. Notwithstanding, a study by Skriner et al. (2015), carried out with 127 children between 5 and 8 years old with OCD showed that, these early-onset patients had a higher Y-BOCS score, with a score of 25.55 points, independently from family history.

Our study showed that, the family history of obsessive-compulsive disorder is present, is in accordance with similar results in the literature, and that, this factor directly influences the history of the disease. This reinforces literature findings that, OCD has biological elements in its pathogenesis, or that at least one OCD subtype appear to have a more evident biological influence. Thus, despite work limitations, such as a retrospective study of medical records, subject to loss of information and a small number of patients, we can conclude that, the family history of OCD can be a risk factor, for greater severity of symptoms.

\section{REFERENCES}

1. Alsobrook II, J., Leckman, J., Goodman, W., Rasmussen, S., \& Pauls, D. (1999). Segregation analysis of obsessive-compulsive disorder using symptom-based factor scores. American Journal Of Medical Genetics, 88(6), 669-675. http://dx. doi. org/10.1002/(sici)1096-8628(19991215)88:6<669::aid-ajmg17>3.0. co;2-n

2. Arumugham, S., Cherian, A., Baruah, U., Viswanath, B., Narayanaswamy, J., Math S., \& Reddy, Y. (2014). Comparison of clinical characteristics of familial and sporadic obsessive-compulsive disorder. Comprehensive Psychiatry; 55(7), 1520-1525. http://dx. doi. org/10.1016/j. comppsych.2014.07.006

3. Black, D. W., Stumpf, A., McCormick. B., Allen, J., Blum, N., \& Noyes, R. (2013). A blind re-analysis of the Iowa family study of obsessive-compulsive disorder. Psychiatry Research, 209(2), 202-206. http://dx. doi. org/10.1016/j. psychres.2013.04.013

4. Brakoulias, V., Starcevic, V., Sammut, P., Berle, D., Milicevic, D., Moses, K., \& Hannan, A. (2011). Obsessive-Compulsive Spectrum Disorders: a Comorbidity and Family History Perspective. AustralasianPsychiatry, 19(2), 151-155. http://dx. doi. org/10.3109/10398562.2010.526718

5. Campos, MCR. (1998) Transtorno obsessivo-compulsivo de início precoce e início tardio: características clínicas, psicopatológicas e de comorbidade (Unpublisheddissertation). Faculdade de Medicina da Universidade de São Paulo, São Paulo, Brazil.

6. Carey G, Gottesman II. (1981). Twin and family studies of anxiety, phobic and obsessive disorders. In: Klien DF, Rabkin J, editors. Anxiety: new research and changing concepts. New York: Raven Press; 117-36

7. Cavallini, M., Pasquale, L., Bellodi, L., \& Smeraldi, E. (1999). Complex segregation analysis for obsessive compulsive disorder and related disorders. American Journal of Medical Genetics, 88(1), 38-43. http://dx. doi. org/10.1002/(sici)10968628(19990205)88:1<38::aid-ajmg7>3.0.co;2-\#

8. Del-Porto, J. (2001). Epidemiologia e aspectos transculturais do transtorno obsessivo-compulsivo. Revista Brasileira De Psiquiatria, 23(suppl 2), 3-5. http://dx. doi. org/10.1590/s1516-44462001000600002 
9. Ferrão, Y., Aguiar, P., Minuzzi, L., Grillo, R., Lopes, R., \& Rosa, R. (2004). Características clínicas e história familiar em pacientes ambulatoriais com transtorno obsessivo-compulsivo. Revista De Psiquiatria Do Rio Grande Do Sul, 26(3), $274-279$. http://dx. doi. org/10.1590/s0101-81082004000300004

10. Fontenelle, L., Mendlowicz, M., \&Versiani, M. (2006). The descriptive epidemiology of obsessive-compulsive disorder. Progress in Neuro-Psychopharmacology And Biological Psychiatry, 30(3), 327-337. http://dx. doi. org/10.1016/j. pnpbp.2005.11.001

11. Gonzalez, C. (1999). Transtorno obsessivo-compulsivo. Revista Brasileira De Psiquiatria, 21(suppl 2), 31-34. http://dx. doi. org/10.1590/s1516-44461999000600009

12. Gonzalez, C. (2001). Aspectos genéticos do transtorno obsessivo-compulsivo. Revista Brasileira De Psiquiatria, 23(suppl 2), 38-41. http://dx. doi. org/10.1590/s1516-44462001000600012

13. Greenberg, D. (1987). Compulsive hoarding. Am J Psychother, 41(3), 409-16.

14. Johnson, B. (2017). Paediatric Anxiety Disorders. BMH Medical Journal - ISSN 2348-392X, 4(3), 91-95.

15. Karno, M., \& Golding, J. (1991). Obsessive compulsive disorder. In: Robins LN, Regier DA, editors. Psychiatric disorders in America: the epidemiologic catchment area study (pp. 204-19). New York: Free Press.

16. Mataix-Cols, D., Marks, I., Greist, J., Kobak, K., \& Baer, L. (2002). Obsessive-Compulsive Symptom Dimensions as Predictors of Compliance with and Response to Behaviour Therapy: Results from a Controlled Trial. PsychotherapyAndPsychosomatics, 71(5), 255-262. http://dx. doi. org/10.1159/000064812

17. Moreno, A., Calo, J., Pinero, M., Zaragoza, C., Navarro, V., \&Marsa, M. (1995). Evolución y respuestaterapéuticaen El trastornoobsesivo-compulsivo. Actas Luso EspNeurolPsiquiatrCienc Afines, 23(1), 9-19.

18. Nelson, E., \& Rice, J. (1997). Stability of diagnosis of obsessive-compulsive disorder in the Epidemiologic Catchment Area study. American Journal Of Psychiatry, 154(6), 826-831. http://dx. doi. org/10.1176/ajp.154.6.826

19. Nestadt, G., Samuels, J., Bienvenu, J., Liang, K., LaBuda, M., Grados, M.,\& Hoehn-Saric R. (2000). A family study of obsessive-compulsive disorder. Arch Gen Psychiatry, 57 (4), 358-63.

20. Nicolini, H., Hanna, G., Baxter, L., Schwartz, J., Weissbacker, K., \& Spence, M. (1991). Segregation analysis of obsessive compulsive and associated disorders. Preliminary results. Ursus Med, 1, 25-8.

21. Nicolini, H., Weissbecker, K., Mejia, J., \& Sanchez de Carmona, M. (1993). Family study of obsessive-compulsive disorder in a Mexican population. Arch Med Res, 24(2),193-8.

22. Pauls, D., \&Alsobrook II J. (1999). The inheritance of obsessive-compulsive disorder. Child AdolescPsychiatrClin N Am, 8:481-96.

23. Pauls, D. L., Raymond, C. L., \& Robertson, M. M. (1991) The genetics of obsessive-compulsive disorder. In: Zohar Y, Insel T, Rasmussen S, editors. Psychobiological aspects of OCD (pp. 89-100). New York: Springer.

24. Rashidi, F., Ahmadipour, E., Shiravand, S., Ahmadiani, A., Asadi, S., \& Shams, J. (2017). Association of the functional serotonin transporter haplotype with familial form of obsessive compulsive disorder in Iranian patients. International Journal Of Psychiatry In Clinical Practice, 1-7. http://dx. doi. org/10.1080/13651501.2017.1353634

25. Rasmussen, S., \&Tsuang, M (1986). Clinical caracteristics and family history in DSM-III obsessive-compulsive disorder. Am J Psychiatry 143 (3), 317-22.

26. Sasson, Y., Zohar, J., Chopra, M., Lustig, M., Iancu, I., \&Hendler T. (1997) Epidemioly of obsessive-compulsive disorder: a 
world view. J Clin Psychiatry, 58(Suppl 12), 7-10.

27. Skriner, L., Freeman, J., Garcia, A., Benito, K., Sapyta, J., \& Franklin, M. (2015). Characteristics of Young Children with Obsessive-Compulsive Disorder: Baseline Features from the POTS Jr. Sample. Child Psychiatry \& Human Development, 47(1), 83-93. http://dx. doi. org/10.1007/s10578-015-0546-y

28. Torres, A., \&Smaira, S. (2001). Quadro clínico do transtorno obsessivo-compulsivo. Revista Brasileira De Psiquiatria, 23(suppl 2), 6-9. http://dx. doi. org/10.1590/s1516-44462001000600003

29. Van Grootheest, D., Cath, D., Beekman, A., \&Boomsma, D. (2005). Twin Studies on Obsessive-Compulsive Disorder: A Review. Twin Research And Human Genetics, 8(05), 450-458. http://dx. doi. org/10.1375/twin.8.5.450

30. Woerner, M., Selles, R., De Nadai, A., Salloum, A., \&Storch, E. (2017). Hoarding in college students: Exploring relationships with the obsessive compulsive spectrum and ADHD. Journal Of Obsessive-Compulsive And Related Disorders, 12, 95-101. http://dx . doi. org/10.1016/j. jocrd.2017.01.004 
